\section{Reshetchenko 5., Popovych N., Shulika B., Porvan A.,} Cherkashyna $\mathbf{N}$.

\title{
EVALUATION OF THE ENVIRONMENTAL STATUS OF AGRICULTURAL RESOURCES IN THE TERRITORY OF UKRAINE UNDER CONDITIONS OF CLIMATE CHANGE
}

Об’єктом дослідження є агрокліматичні ресурси на територї Украӥни, що характеризуються сукупністю агрокліматичних факторів, які діють на умови росту та розвитку рослин та формують урожайність сільськогосподарських культур. Ці фактори мають кількісне значення та визначаються агрокліматичними показниками, що вказують на взаємозв'язок між факторами клімату та умовами росту, розвитку рослин, формування врожаю.

Одним з найбільш проблемних місць оцінки клімату для сільськогосподарського виробництва є процеси теплообміну та вологообміну в системі грунт-рослина-атмосфера, де відбуваються біофізичні та фізіологічні процеси. Крім того, треба враховувати вимоги рослин до навколишнього середовища: мінімальні та критичні температури повітря, грунту; суми температур, які необхідні для визрівання сільськогосподарських культур; кількість вологи.

В ході дослідження використовувалися моделі для прогнозування потениійних впливів змін клімату на продуктивність сільського господарства та вивчення варіантів адаптацї до ицх змін.

Очінка агрокліматичних ресурсів території проводилася за показниками теплозабезпеченості, де розраховувалися суми активних та ефективних температур. Для оцінки екологічного стану агрокліматичних ресурсів використовувався показник стійкості кліматичних умов. На основі цього очікується збільшення тривалості вегетаційного періоду сільськогосподарських культур за рахунок збільшення його теплозабезпеченості.

На прикладі Харківської області надалі визначалися основні риси сучасного температурно-вологісного режиму. Встановлено, що найбільше зростання температури повітря зафіксовано з середини 70-х років минулого століття.

Встановлено, що в річному ході температура повітря буде підвищуватися з середнім коефіцієнтом лінійного тренду 0,3-0,4 ${ }^{\circ}$ С на 10 років. Амплітуди коливань температури повітря досить суттєві, що дестабілізує кліматичні умови на півночі. Південна та південно-західна частина регіону мають вищий показник стійкості погодних умов за рахунок усталеного температурного режиму повітря та характеру підстильної поверхні.

Завдяки цьому забезпечується можливість отримання заходів, щодо адаптацї сільського господарства до сучасних змін агрокліматичних ресурсів. Запропоновані заходи адаптацї сільського господарства до сучасних кліматичних змін можуть бути успішно застосовані й у крайнах-сусідах, зокрема Молдові, Білорусі.

Ключові слова: агрокліматичні ресурси, гідротермічний показник, біокліматичний потениіал, адаптація до змін клімату.

\section{Introduction}

Adoption of urgent measures to combat climate change and its consequences is one of the 17 global sustainable development goals approved by the United Nations Summit in 2015 [1]. Forecasted climate changes in the future will lead not only to economic losses, but also to uncontrolled migration of people, new diseases and increased environmental burden on the territory [2]. On the territory of Eastern Europe, where Ukraine is located, signs of climate change are manifested in [3]:

- temperature extremes;

- an increase in the number of hot days;

- general decrease of the amount of precipitation (against

the background of its sharp increase in some areas);

- catastrophic floods and droughts;

- forest fires and desertification.
Agriculture is the most dependent on the climatic conditions and one of the major spheres of material production in Ukraine. It depends on the agro-climatic resources of the territory formed on the basis of the characteristics of temperature and humid air fields. Experts point out that existing state programs on sustainable agricultural development remain situational, without a coherent longterm strategic perspective. This reduces the possibility of mitigating the effects of climate change and related crisis phenomena in the agro-sphere [2]. It is significant that the actual Strategy for the Development of Agriculture and Rural Areas of the country was developed without taking into account climatic aspects [4].

Instead, the draft Strategy of Sustainable Development of Ukraine until 2030 recommends to include climate change responses in policy, strategy and planning at the national, sectoral and regional levels. The need to carry 
out scientifically grounded adjustment of agricultural practices is emphasized, taking into account growing risks of extreme weather events [5], namely:

- terms and methods of sowing;

- soil treatment;

- systems of soil protection and reclamation measures; - quantity and method of mineral and organic fertilizer application;

- systems of agrochemical protection of plants.

To solve this problem correctly, an in-depth analysis of existing data [6], a detailed and thorough study of modern changes in agro-climatic resources both at the level of the whole country and in its individual regions, taking into account comprehensive links between elements of agroecocoenosis and changes in the environment conditions is required. Under this they understand: the amount of solar radiation, air and soil temperature and humidity, wind speed, repeatability of atmospheric phenomena, etc. Such studies will help to plan, develop and implement complex agrotechnical measures, considering current changes in the key climatic factors of the environment: air temperature and the amount of precipitation.

\section{The object of research and its technological audit}

The object of research is agro-climatic resources on the territory of Ukraine characterized by a combination of agro-climatic factors acting on the conditions of growth and development of plants and forms the productivity of agricultural crops. These factors are quantitative and determined by agroclimatic indicators, showing the relationship between climate factors and growth conditions, plants development, crop formation. Assessing the impact of climate on agricultural production, it is necessary to take into account a number of indicators:

- thermal and light;

- humidity regime of the territory;

- conditions for overwintering of winter and peren-

nial crops with requirements for minimum air and soil temperatures;

- thickness of the snow cover;

- meteorological phenomena unfavorable for agricultural production (drought, showers, floods, frost, droughts, hail).

It is known that during growth and development, agricultural crops are affected by various external factors: lighting, air temperature and soil moisture, physical and mechanical properties chemical composition of the surface layer, oxidation-reducing processes. All these environmental factors influence both physiological properties of plants, conditions for seeds germination, spouting and formation of yield. The influence of any one indicator depends on the quantitative expression of the remaining factors. Under conditions of the combined action of the environment, the importance of any agroclimatic index in the life of plants is uneven. Thus, the main factors in plant life and secondary are distinguished. The first ones include light, heat, moisture and air, which are necessary for plants and contribute directly to the conditions of growth, development; others are secondary indicators that increase (weaken) the effect of the former ones.

One of the most problematic places for climate assessment of agricultural production is the processes of heat and water exchange in the soil-plant-atmosphere system, where biophysical and physiological processes take place. In addition, we must take into account the requirements of plants to the environment: minimum and extreme air, soil temperatures; sums of temperatures required for crops ripening; amount of moisture Against the background of significant fluctuations in weather conditions, shortcomings in crop yields are caused by many factors. Thus, when solving practical problems, there is a need to assess the impact of agro-climatic indicators on crop yields.

\section{The aim and objectives of research}

The aim of research is determination of peculiarities of modern changes in agro-climatic resources on the territory of Ukraine and Kharkiv region.

Based on the aim, the following objectives need to be addressed:

1. To conduct a statistical analysis of the main agroclimatic indicators on the territory of Ukraine for the periods 1891-1935 and 1935-1960.

2. To calculate agro-climatic indicators at the regional level on the example of Kharkiv region for the period 2001-2014.

3. To evaluate ecological conditions of agro-climatic resources in the territory of Kharkiv region by means of climatic conditions stability indicator.

4. To identify possible measures for adapting agriculture to modern changes in agro-climatic resources.

\section{Research of existing solutions of the problem}

It is known that agro-climatic resources of any territory are conditioned by distribution of radiation, heat and water balances under the influence of atmospheric circulation. Radiation regime and thermal balance of vegetation are determined by different regression equations. Models and scenarios of the dynamics of global and regional air temperature, precipitation in different warming conditions are presented in [7]. The author also calculated possible scenarios for changing air temperature and the amount of precipitation in the territory of Ukraine in warming conditions.

Integration of climate risk information into strategic planning is now a global priority [8]. In particular, modern warming affects the conditions of growth, development and production of agricultural crops. Instability of meteorological indicators can cause significant losses to agricultural producers due to the volatility of gross crop yields that are key crops in the country [9].

European agriculture, based on progressive farming practices, is focused on the production of high-quality food products and is more sensitive to meteorological hazards [10]. Farmers in Europe are currently adapting to climate change, in particular by adjusting the cultivation terms and choosing other types of crops. Surveys show a high proportion of negative expectations about the impact of climate change on crop production throughout Europe, even in northern countries [11].

Ecophysiological models are widely used to predict the potential impacts of climate change on agricultural productivity and study options for adaptation to these changes [12]. For today, forecasts of changes in crops in Europe under the influence of climate change are almost 
entirely based on the results of yield growth models. These patterns, as a rule, do not cover all important aspects related to crop management or relevant environmental factors. In addition, studies on crop modeling often have serious limitations on sowing crops [13].

Anthropogenic impact is among the many causes of global warming, characterized by increased emissions of greenhouse gases. The authors of the study [14] indicate the following environmental effects of global warming that have already manifested or may emerge in the near future in Ukraine:

- raising levels of the Black and Azov Seas;

- spatial transformation of steppe phytosystems structure; - changes in marine ecosystems in the northern part of the Sea of Azov;

- excitation of catastrophic weather phenomena;

- development of desertification in the southern and southeastern regions;

- impact of climate change on agriculture;

- reduction of water resources.

Disregarding a significant increase in the yield of agricultural crops, fluctuations of yields in some years are described by a large number of factors:

- genetic and selection qualities;

- quantity and quality of fertilizers;

- terms and norms of fertilizer application;

- pest and disease control means;

- types of agricultural machinery;

- weather conditions that are characterized by a large randomness.

Fluctuations of weather conditions are influenced by large-scale atmospheric processes, which form the temperature-humidity mode of the underlying surface. Agroclimatic resources of the territory determine functioning conditions of the economy of the country, especially rural productivity. They have a significant impact on the formation of the harvest, its yield. One third of the territory of Ukraine is in the zone of stable yield, and the rest is characterized by a tendency to its decrease [15]

Beginning from the 80 s of the XX century, Ukraine has the longest and almost continuous period of warming. The decrease in annual air temperature and dry conditions was recorded in 2005, 2007, 2010, 2012, 2014. The highest average annual air temperature over the entire period of instrumental observations was recorded in 2007, where the excess of the norm varied within $2-3{ }^{\circ} \mathrm{C}$ throughout the territory.

Arid phenomena arise due to a set of natural processes (a long idle period, insufficient soil moisture, significant temperature of the surface layer of soil, etc.) characterized by unidirectional actions on agroecocoenoses over a certain period of time. They create lack of air and soil humidity against the background of high temperatures.

There are different indicators that establish the relationship between the amount of rainfall and the thermal regime of the territory during the growing season in any region. Common indicators are:

- G. T. Selyaninov's (GTK) hydrothermal coefficient [9];

- D. A. Pedy's (Sa) index of atmospheric dryness [9];

- Palmer's Drought Severity Index (PDSI);

- Standardized precipitation index (SPI);

- Rainfall Index - Evapotranspiration (SPEI);

- normalized vegetation index (NDVI) [16].

These parameters, used in various scientific schools, have certain limitations related to the method of calculation. However, they allow them to be used as indicators of quantitative relationships between weather conditions and crop productivity for prediction purposes.

These indicators allow to identify zonal features of agro-climatic resources of the territory. According to them, the study area can be divided into relatively homogeneous agro-climatic areas, where it is possible to apply separate agrotechnical measures. Azonic features that arise due to the peculiarities of the underlying surface (forests, swamps, tracts, ravines, etc.) are established by means of a detailed mapping method for spatial boundaries and separation of isolated agro-climatic regions into mesoscale units. This technique was applied to the territory of Kharkiv region characterized by significant heterogeneity of the relief and various types of active surface.

A study [17] compares several systems of agroclimatic classification and vegetation maps. The EPPO region (European and Mediterranean Plant Protection Organization) is divided into four agro-climatic zones (Mediterranean, Marine, Northeastern, Central), in which agro-climatic conditions can be considered identical.

Today's changes in the structure of agricultural production in Ukraine (the use of new varieties of crops, changes in crops, the use of modern agrotechnologies) contribute to the development of reliable methods for assessing agroclimatic resources and agro-climatic zoning. Only an integrated approach will help to establish meaningful and reliable links between these factors and the productivity of crops. This approach is based on the study of physical and geographical patterns of the territory, agro-ecological objects, peculiarities of agrotechnologies with the definition of their impact on agricultural crops yields at different levels of production organization.

A resource approach to climatic conditions is aimed at solving practical problems and establishing risks in the conditions of natural hydrometeorological phenomena formation. This approach can contribute to the development of adaptation measures to mitigate climate change in selected regions, and is therefore promising.

Analysis of literature shows that the territory of Ukraine as a whole has favorable agroclimatic resources characterized by the optimal ratio of heat and moisture. However, the expected climate change may have irreversible consequences for the area under study, reduction of food safety level being one of them, especially in arid regions [3]. Therefore, it is necessary to establish possible environmental risks and prospects for the agrarian sector of the economy in the country.

\section{Methods of research}

Statistical analysis of time series of meteorological parameters of air temperature and atmospheric precipitation was performed according to the results of observations at meteorological stations of Ukraine (Table 1, 2).

To identify trends in agro-climatic conditions, data from climatic reference books and observations from several periods were used: $1891-1935,1935-1960,1961-1990$, 2001-2014. The selected time interval of 30-50 years characterizes climate conditions with the average monthly values of air temperature and rainfall.

Analysis of agroclimatic changes trends was performed by comparing the average long-term characteristics of meteorological and agrometeorological indicators. Reference values are meteorological indicators for the period 1961-1990, which corresponds to the climatic norm. 
Average monthly air temperature (1891-1935)

\begin{tabular}{|l|c|c|c|c|c|c|c|c|c|c|c|c|}
\hline Meteoralogical station & I & II & III & IV & V & VI & VII & VIII & IX & X & XI & XII \\
\hline Chernihiv & -6.9 & -6.2 & -2.0 & 6.8 & 14.4 & 17.8 & 19.7 & 18.4 & 13.5 & 7.1 & 1.1 & -3.7 \\
\hline Sumy & -7.5 & -6.7 & -2.3 & 6.7 & 14.0 & 18.1 & 19.6 & 18.4 & 13.3 & 6.4 & 0.2 & -5.0 \\
\hline Kyiv & -6.0 & -5.0 & -0.4 & 6.7 & 14.7 & 17.9 & 19.6 & 18.7 & 14.0 & 7.6 & 1.4 & -3.3 \\
\hline Lviv & -4.1 & -3.3 & 1.1 & 7.9 & 14.8 & 16.7 & 18.5 & 17.3 & 13.6 & 8.1 & 7.4 & -1.9 \\
\hline Ternopil & -5.9 & -4.4 & -0.2 & 7.1 & 13.5 & 16.7 & 18.2 & 17.5 & 13.1 & 7.6 & 1.9 & -2.8 \\
\hline Vinnytsia & -5.8 & -4.8 & -0.6 & 7.2 & 13.6 & 17.1 & 18.7 & 17.8 & 13.5 & 7.3 & 1.8 & -2.8 \\
\hline Uman' & -5.9 & -4.8 & -0.3 & 7.5 & 14.4 & 17.6 & 19.5 & 18.7 & 13.9 & 7.7 & 1.5 & -3.1 \\
\hline Poltava & -6.3 & -6.2 & -0.3 & 7.6 & 15.0 & 18.4 & 20.6 & 19.6 & 14.3 & 7.5 & 0.9 & -4.3 \\
\hline Kharkiv & -7.1 & -6.5 & -1.2 & 7.7 & 15.0 & 18.6 & 20.6 & 19.6 & 14.3 & 7.5 & 0.9 & -4.6 \\
\hline Uzhhorad & -3.1 & -1.0 & -3.9 & 10.8 & 15.5 & 18.8 & 20.4 & 19.7 & 15.9 & 9.8 & 5.5 & 0.1 \\
\hline Kropyvnytsky & -5.5 & -4.6 & 0.3 & 8.3 & 15.2 & 18.7 & 20.8 & 19.9 & 14.7 & 8.4 & 2.1 & -2.8 \\
\hline
\end{tabular}

Average monthly air temperature (1935-1960)

Table 2

\begin{tabular}{|l|c|c|c|c|c|c|c|c|c|c|c|c|}
\hline Meteoralogical station & I & II & III & IV & V & VI & VII & VIII & IX & X & XI & XII \\
\hline Chernihiv & -6.5 & -6.4 & -1.5 & 6.5 & 14.3 & 17.2 & 19.2 & 17.8 & 12.8 & 6.8 & 0.5 & -4.2 \\
\hline Sumy & -7.8 & -7.6 & -2.3 & 6.2 & 14.4 & 17.4 & 19.6 & 18.2 & 13.0 & 6.6 & -0.1 & -5.6 \\
\hline Kyiv & -5.9 & -5.3 & -0.5 & 7.1 & 14.7 & 17.4 & 19.3 & 18.2 & 13.6 & 7.7 & 1.1 & -3.7 \\
\hline Lviv & -3.8 & -2.8 & 1.8 & 7.6 & 13.8 & 16.6 & 18.3 & 17.5 & 13.6 & 8.8 & 2.7 & -1.4 \\
\hline Ternopil & -5.5 & -4.4 & 0.3 & 6.9 & 13.7 & 16.6 & 18.3 & 17.2 & 12.9 & 7.5 & 1.5 & -3.0 \\
\hline Vinnytsia & -5.7 & -4.8 & 0.2 & 7.1 & 14.1 & 16.8 & 18.8 & 17.6 & 13.3 & 7.9 & 1.5 & -3.2 \\
\hline Kherson & -3.0 & -2.5 & 2.8 & 9.6 & 16.6 & 20.4 & 23.2 & 22.0 & 16.8 & 11.2 & 4.2 & -0.7 \\
\hline Poltava & -7.1 & -6.6 & -1.2 & 7.1 & 14.9 & 17.9 & 20.4 & 19.3 & 14.2 & 7.6 & 0.5 & -4.8 \\
\hline Kharkiv & -7.4 & -7.0 & -1.6 & 7.1 & 15.0 & 18.1 & 20.3 & 18.9 & 13.5 & 7.2 & 0.4 & -5.2 \\
\hline Uzhhorad & -2.9 & -1.4 & 4.3 & 10.0 & 15.4 & 17.9 & 19.9 & 19.0 & 15.1 & 10.1 & 4.3 & -0.2 \\
\hline Kropyvnytsky & -5.5 & -4.9 & 0.4 & 7.9 & 15.2 & 18.3 & 20.9 & 19.7 & 14.5 & 8.6 & 1.9 & -3.2 \\
\hline Mykolaiv & -3.6 & -3.0 & 2.3 & 9.2 & 16.3 & 19.9 & 22.9 & 22.0 & 16.8 & 10.8 & 3.8 & -1.3 \\
\hline Odesa & -2.8 & -2.2 & 2.4 & 8.5 & 15.8 & 19.8 & 22.6 & 21.7 & 16.9 & 11.5 & 4.9 & -0.1 \\
\hline Chernivtsi & -4.8 & -3.4 & 1.8 & 8.3 & 14.5 & 17.4 & 19.2 & 18.6 & 14.2 & 8.8 & 2.3 & 1.9 \\
\hline Dnipro & -5.7 & -5.1 & 0.5 & 8.5 & 16.2 & 19.3 & 22.2 & 21.0 & 15.6 & 9.1 & -2.4 & -3.3 \\
\hline Zaporizhzhia & -5.3 & -4.9 & 0.8 & 8.5 & 16.0 & 19.4 & 22.6 & 21.2 & 15.6 & 9.2 & 2.1 & -3.0 \\
\hline
\end{tabular}

Assessment of agro-climatic resources of the territory was carried out on the indicators of heat supply, the total active and effective temperatures were calculated. Moisture resources characterize the monthly amount of atmospheric precipitation and T. G. Selyaninov's hydrothermal coefficient [18]. These values were calculated by the average monthly values of air temperature and the amount of precipitation.

According to Tables 1 and 2 total active and effective temperatures in the territory of Ukraine were calculated (Table 3). Under the sum of active temperatures we understand the available heat resources, determining the possibility of crops ripening. Under the sum of effective temperatures we understand the difference between the average daily air temperature and the biological zero of the agricultural plant (Table 4) for the period April-October. The total effective temperatures for grain crops $\left(5^{\circ} \mathrm{C}\right)$ were calculated in the paper.
An indicator of the humidity of the territory is T. G. Selyaninov's hydrothermal coefficient [18], characterized by the ratio of precipitation amount $\left(\sum u\right)$ for the period with average daily air temperatures above $10{ }^{\circ} \mathrm{C}$ to the sum of active temperatures $\left(\sum T_{>10}{ }^{\circ} \mathrm{C}\right)$.

Bioclimatic potential (BCP) allows for zoning of the territory under similar agro-climatic conditions. It takes into account the effect of heat and moisture on crop productivity [19].

Index of climatic conditions stability $(X)$ [20] was used to assess the ecological conditions of agro-climatic resources. This index is calculated as the difference between the mean and the minimum values in a series of indicators in the initial values divided by the amplitude of the magnitude multiplied by 10 . It is proposed to use the characteristics of climatic conditions stability assessment presented in Table 5 . 
Total active and effective temperatures on the territory of Ukraine for periods: 1891-1935, 1935-1960

\begin{tabular}{|c|c|c|c|c|}
\hline \multirow{2}{*}{ Meteorological station } & \multicolumn{2}{|c|}{ 1891-1935 } & \multicolumn{2}{|c|}{ 1935-1960 } \\
\hline & Total active temperatures & Total effective temperatures & Total active temperatures & Total effective temperatures \\
\hline Chernihiv & 2490.3 & 960.3 & 2566.5 & 1036.5 \\
\hline Sumy & 2530.2 & 1000.2 & 2554.0 & 1024.0 \\
\hline Kyiv & 2548.2 & 1018.2 & 2600.0 & 1070.0 \\
\hline Lviv & 2443.6 & 913.6 & 2477.6 & 947.6 \\
\hline Ternopil & 2410.2 & 880.2 & 2419.2 & 889.2 \\
\hline Vinnytsia & 2468.5 & 938.5 & 2471.1 & 941.1 \\
\hline Kherson & 3379.0 & 1539.0 & 2575.6 & 1045.6 \\
\hline Poltava & 2655.6 & 1125.6 & 2692.2 & 1162.2 \\
\hline Kharkiv & 2628.2 & 1098.2 & 2698.2 & 1168.2 \\
\hline Uzhhorad & 3286.4 & 1146.4 & 3088.6 & 1258.6 \\
\hline Kropyvnytsky & 2713.8 & 1183.8 & 2734.9 & 1204.9 \\
\hline
\end{tabular}

Biological minimum temperatures for the development of different crops

\begin{tabular}{|c|c|c|}
\hline \multirow{2}{*}{ Сгор } & Biological minimum temperature, ${ }^{\circ} \mathrm{C}$ \\
\cline { 2 - 3 } & Beginning of growth & Ripening \\
\hline \multicolumn{3}{|c|}{ Cereal } \\
\hline Winter wheat & 5 & 10 \\
\hline Spring wheat & 5 & 12 \\
\hline Barley & 5 & 10 \\
\hline Buckwheat & 7 & 10 \\
\hline Corn & 10 & 10 \\
\hline & Legume crops \\
\hline Pea & 5 & 10 \\
\hline Bean & 12 & 12 \\
\hline Soy & 10 & 10 \\
\hline \multicolumn{3}{|c|}{ Growing сторь } \\
\hline Sunflower & 8 & 10 \\
\hline
\end{tabular}

Table 5

Characteristics of the climatic conditions assessment of the territory

\begin{tabular}{|c|c|}
\hline $\begin{array}{c}\text { Stability Index value } \\
\text { (points) }\end{array}$ & $\begin{array}{c}\text { Qualitative assessment } \\
\text { of climatic conditions }\end{array}$ \\
\hline $0.0-3.0$ & Low \\
\hline $3.1-6.0$ & Satisfactory \\
\hline $6.1-8.0$ & Good \\
\hline $8.1-10.0$ & High \\
\hline
\end{tabular}

The environmental conditions of the agroclimatic resources of the territory (evaporation processes, temperature regime, humidification) are influenced by the main climatic indicators - air temperature, wind speed and rainfall. An integrated coefficient of sustainability for the overall assessment at the regional level was calculated for the period 2001-2015 for the territory of Kharkiv region.

\section{Research results}

Based on the calculations (Table 4) graphics of the distribution of heat resources were built represented by the total active and effective temperatures (Fig. 1, 2).

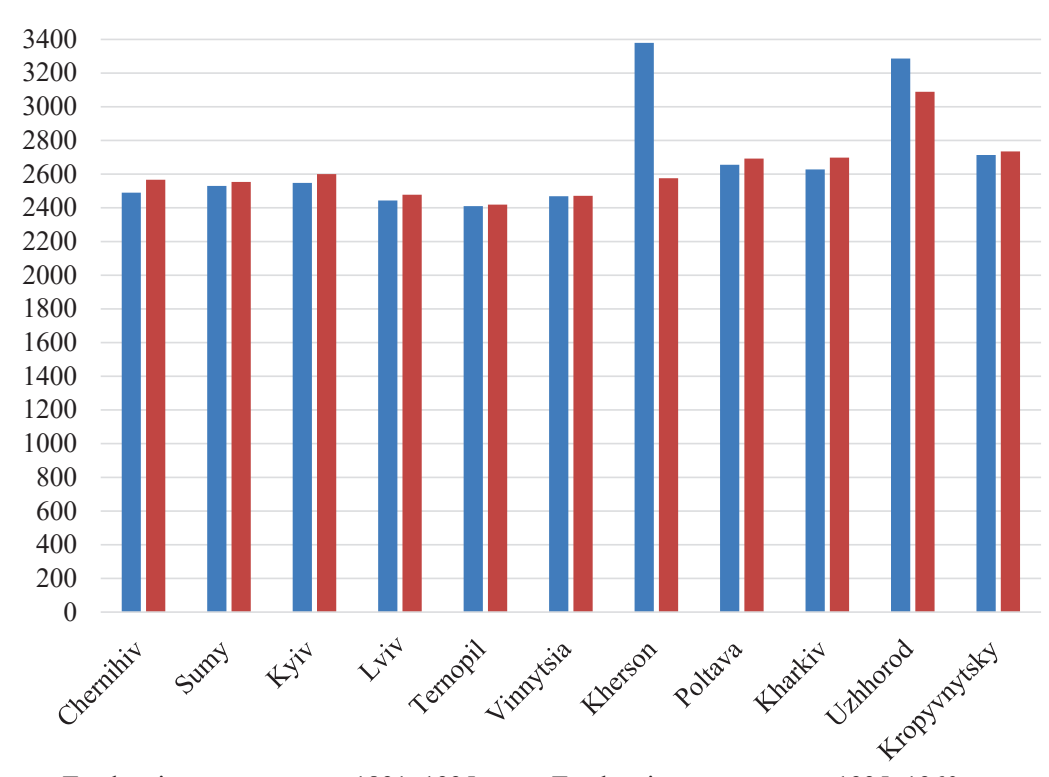

- Total active temperatures 1891-1935 - Total active temperatures 1935-1960

Fig. 1. Distribution of total active temperatures (1891-1935, 1935-1960)

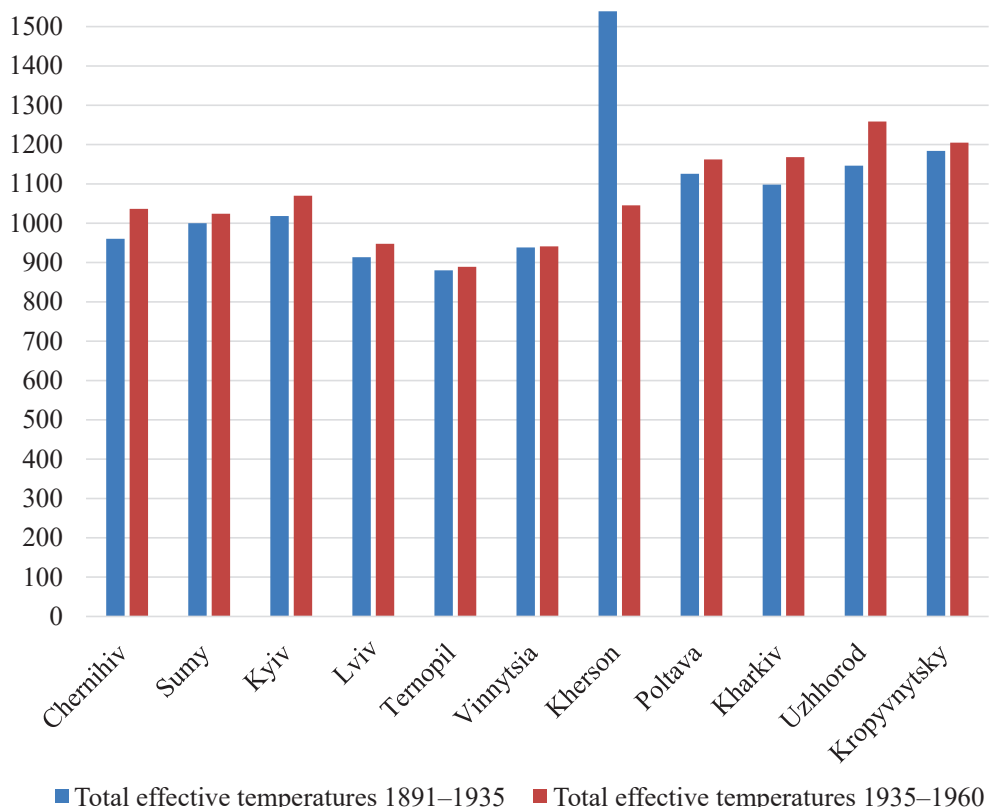

Fig. 2. Distribution of total effective temperatures (1891-1935, 1935-1960) 
Isotherms for the period 1891-1935 have latitudinal distribution that characterizes weather conditions developed under the influence of regional atmospheric circulation. Significant changes in atmospheric circulation are noted from the second half of the 20th century and isotherms approach the meridional distribution. Indicators of activetemperature sums greater than $10{ }^{\circ} \mathrm{C}$ during the period 1891-1935 range from $2500{ }^{\circ} \mathrm{C}$ to $3500{ }^{\circ} \mathrm{C}$ in the south of the country (Fig. 1). A part of the territory where the sum of active temperatures is fixed within $2100-2500{ }^{\circ} \mathrm{C}$ stands out. In the south-east, the heat supply of the territory increases, extending to the central part of the country.

Regularities of the spatial distribution of total active and effective temperatures are similar to the sums of active temperatures, there is a tendency of growth. The conducted research confirmed that there is reorganization of heat resources in the direction of their growth due to the features of atmospheric circulation processes on the investigated area.

The analysis of heat supply indicators shows that the predominantly flat territory of the country is divided into three main zones:

1) the sum of active temperatures above $3000{ }^{\circ} \mathrm{C}$;

2) the sum of active temperatures $2600-3000{ }^{\circ} \mathrm{C}$;

$3)$ the sum of active temperatures - up to $2500{ }^{\circ} \mathrm{C}$.

On the basis of this, an increase in the duration of the growing season of agricultural crops is expected due to increase of its heat supply.

Because of significant fluctuations of temperature parameters of the cold period spring processes begin 2-3 weeks earlier. The extension of active vegetation period of plants for 7-10 days was recorded. Heat supply of the growing season on average increased by $70-100{ }^{\circ} \mathrm{C}$. It should be taken into account that such temperature fluctuations are accompanied by a decrease in the amount of precipitation in winter, which negatively affects the formation of spring humidification. According to experts, further increase in air temperature is expected on the territory of Ukraine. In the future, the impact of climate change on agricultural production will increase.

On the example of the territory of Kharkiv region, the main features of the current temperature-humidity regime were further determined. It has been established that the greatest increase in air temperature has been recorded since the mid-70s of the last century marked in winter and summer periods. The average monthly air temperature increased in winter by $1.3^{\circ} \mathrm{C}$, in spring - by $1.1{ }^{\circ} \mathrm{C}$, summer - by $1.7^{\circ} \mathrm{C}$ and autumn - by $1.2{ }^{\circ} \mathrm{C}$. In the spring months, the greatest warming was registered in March $\left(1.7^{\circ} \mathrm{C}\right)$. In comparison with the climatic norm July (by $2.4{ }^{\circ} \mathrm{C}$ ) and August (by $2.0{ }^{\circ} \mathrm{C}$ ) became hotter. In autumn, the greatest increase in air temperature was recorded in November (by $1.4^{\circ} \mathrm{C}$ ). Consequently, the stability of the snow cover and the duration of the winter period (up to 20 days versus 120-140) decreased, there were sharp fluctuations of air temperature between months and seasons (from $-15^{\circ} \mathrm{C}$ to $+7^{\circ} \mathrm{C}$ ), the duration of the frost-free period (180-226 days) on the territory of Kharkiv region increased. The most intense warming is characteristic of the last decade, namely 2001-2010.

It has been established that during the annual course the air temperature will increase with an average linear trend of $0.3-0.4{ }^{\circ} \mathrm{C}$ for 10 years. The increase in temperature is expected due to an increase in its minimum and average values during the year. Significant fluctuations in warming are observed in the winter period (the linear trend coefficient is $0.2-0.5{ }^{\circ} \mathrm{C}$ for 10 years).

High air temperature described by the values of $25.0^{\circ} \mathrm{C}$ and above, with prolonged low relative humidity of air and dry cavities leads to significant losses of crops. For example, in 2007, droughts in central and southern regions of the country destroyed about 1.1 million hectares of winter and spring crops on the area of almost 10 million hectares. Losses due to droughts can be significantly reduced by changing irrigation regimes, choosing the optimal time of sowing, measures for plants care

Kharkiv region is characterized by the highest repeatability of high temperatures (more than $25.0{ }^{\circ} \mathrm{C}$ ) in July (116 cases), June (43), August (56). In general, there are 248 cases with temperature above $25.0^{\circ} \mathrm{C}$ and very high temperature (more than $30.0^{\circ} \mathrm{C}$ ). The smallest number of them (15) was recorded in May (Fig. 3).

Spatial distribution of rainfall for growing conditions and development of grain crops is an important indicator. Dry conditions are set at small values of the SCC parameter (less than 0.5). Recent studies [21, 22] show a decrease in annual rainfall in Ukraine [23, 24]. In 2007 they were shortage of the norm at $25-40 \%$ in the southeastern and central regions. As a result of aridity, there is a decrease in the zone of sufficient soil moisture. There is a danger of desertification in the southern part of the territory through a set of factors, among which reduction of rainfall is one of the most important. Such processes cannot be ignored, especially in areas where the ecological balance is disrupted, for example, deforestation.

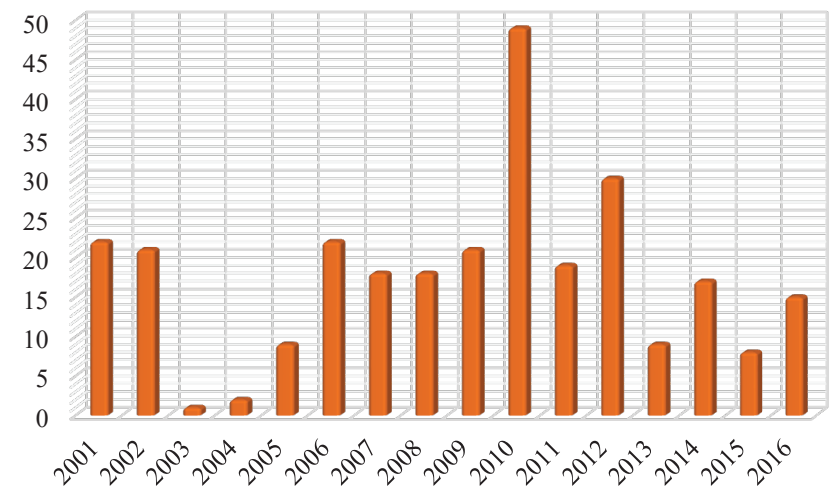

Fig. 3. Repetition of high air temperatures ( $25^{\circ} \mathrm{C}$ and above) at Kharkiv station

Agro-climatic resources in the north-east of the country were studied on the example of Kharkiv region, where agriculture is a significant part of the economy (Table 6).

The analysis of rainfall changes for the period 1951-2010 indicates the oscillatory mechanism at intervals of 2030 years (Fig. 4, 5). The amount of precipitation decreases in summer and autumn (the linear trend is $1 \mathrm{~mm}$ every 10 years), slight increases in rainfall are recorded in winter and spring.

The amount of precipitation on the territory changes unevenly throughout the year and seasons. In the spring period, there is a tendency for insignificant growth, and in autumn its amount practically does not change. It is known that under weak droughts yields can decrease by $20 \%$, under severe ones by $20-40 \%$, under very severe, which are rare, but covering large areas - by more than $50 \%$. 
Table 6

Agroclimatic resources of Kharkiv region

\begin{tabular}{|c|c|c|c|c|c|c|}
\hline \multirow{2}{*}{$\begin{array}{c}\text { Administrative } \\
\text { districts }\end{array}$} & \multirow{2}{*}{$\begin{array}{l}\text { Duration of } \\
\text { frost - free } \\
\text { period (days) }\end{array}$} & \multirow{2}{*}{$\begin{array}{c}\text { Total active tem- } \\
\text { peratures above } \\
10^{\circ} \mathrm{C}\end{array}$} & \multicolumn{2}{|r|}{ Total pгеcipitation, mm } & \multirow{2}{*}{$\begin{array}{l}\text { Total evaporation for } \\
\text { a period with tempera- } \\
\text { ture above } 10^{\circ} \mathrm{C}\end{array}$} & \multirow{2}{*}{$\begin{array}{c}\text { Hydrothermal } \\
\text { coefficient }\end{array}$} \\
\hline & & & Рег уеаг & For a period with temperature above $10^{\circ} \mathrm{C}$ & & \\
\hline Balakliysky & 160 & 2800 & 500 & 260 & 600 & 0.93 \\
\hline Barvinkivsky & 165 & 2900 & 490 & 280 & 630 & 0.93 \\
\hline Blysniukivsky & 165 & 2900 & 490 & 270 & 640 & 0.93 \\
\hline Bohodukhivsky & 155 & 2650 & 543 & 280 & 560 & 1.06 \\
\hline Borivsky & 160 & 2700 & 510 & 280 & 570 & 1.04 \\
\hline Valkivsky & 160 & 2700 & 573 & 280 & 570 & 1.04 \\
\hline Vel.Burlutsky & 155 & 2650 & 549 & 250 & 580 & 0.94 \\
\hline Vovchansky & 150 & 2700 & 520 & 280 & 570 & 1.04 \\
\hline Dvorichansky & 155 & 2700 & 500 & 250 & 620 & 0.93 \\
\hline Derhachivsky & 145 & 2720 & 530 & 280 & 560 & 1.04 \\
\hline Zachepylivsky & 170 & 2850 & 564 & 280 & 610 & 0.8 \\
\hline Zmiivsky & 160 & 2750 & 557 & 270 & 570 & 1.00 \\
\hline Zolochivsky & 155 & 2650 & 537 & 280 & 560 & 1.06 \\
\hline Iziumsky & 165 & 2900 & 575 & 290 & 640 & 1.00 \\
\hline Kehichivsky & 165 & 2750 & 500 & 280 & 610 & 0.98 \\
\hline Kolomatsky & 160 & 2700 & 573 & 280 & 570 & 1.04 \\
\hline Krasnohradsky & 170 & 2800 & 564 & 290 & 600 & 1.03 \\
\hline Krasnokutsky & 160 & 2700 & 510 & 280 & 560 & 1.04 \\
\hline Kupiansky & 160 & 2750 & 502 & 280 & 620 & 1.02 \\
\hline Lozivsky & 165 & 2850 & 558 & 270 & 620 & 0.93 \\
\hline Novovodolazhsky & 160 & 2700 & 500 & 270 & 570 & 1.00 \\
\hline Pervomaisky & 160 & 2750 & 561 & 270 & 570 & 0.98 \\
\hline Pechenizsky & 155 & 2700 & 520 & 280 & 590 & 1.04 \\
\hline Sakhnovshchynsky & 165 & 2800 & 470 & 270 & 610 & 0.93 \\
\hline Kharkivsky & 155 & 2700 & 559 & 270 & 570 & 1.00 \\
\hline Chuhuivsky & 155 & 2750 & 520 & 280 & 570 & 1.02 \\
\hline Shevchenkivsky & 155 & 2700 & 520 & 280 & 610 & 1.04 \\
\hline
\end{tabular}

Droughts are often exacerbated by dry winds, causing damage to plants in different phases of development and reducing their productivity. In addition, the amount of rainfall is not as important as its distribution, the nature of which tends to increase the number of inefficient rains, drains, especially against the background of high air temperatures. If the monthly rainfall norm falls within 1-2 days or half a day, then they can cause significant damage to agricultural production.

The analysis of SCC spatial distribution on the territory of Kharkiv region indicates that the humidification regime tends to increase the dryness in the east and south of the region. The most favorable humidification conditions are recorded in the north of Kharkiv region. Instead, the average SCC value on the territory of Kharkiv region is 0.97 . The highest SCC values are observed in the northwestern parts of the region (more than 1.02), the lowest in the eastern and southern (less than 0.93). The SCC value in May increased (from 0.90 to 0.94), and in July and August - decreased. In July-August periods with moderate drought can be expected based on HTC value. Prolonged inadequate moisturizing causes inhibition of crop growth, reduced productivity and poor harvest.

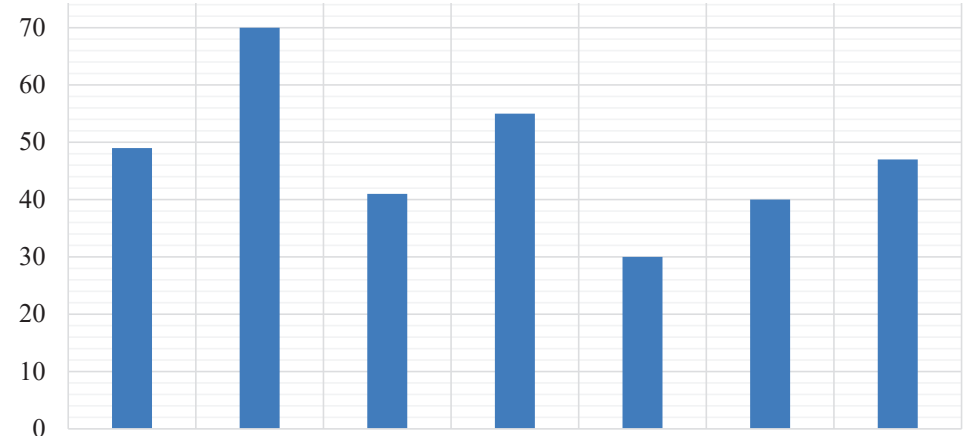

1951-1960 1961-1970 1971-1980 1981-1990 1991-2000 2001-2010 2011-2016

Fig. 4. Dynamics of monthly precipitation at the meteorological station Kharkiv (January)

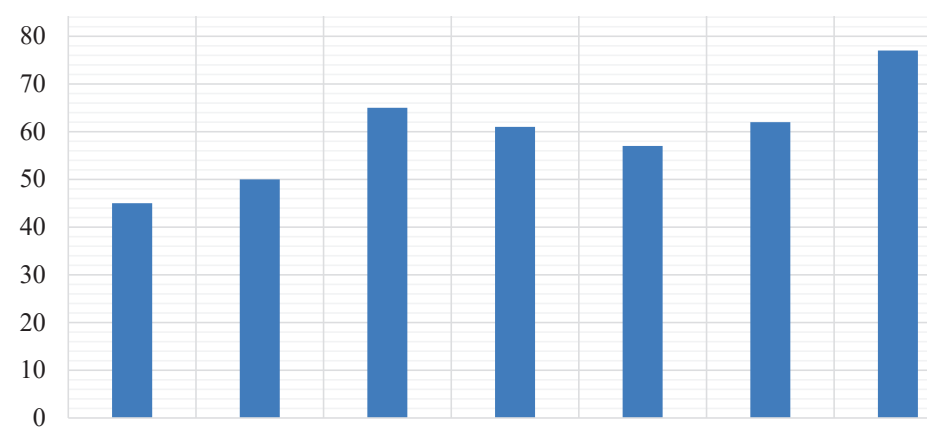

1951-1960 1961-1970 1971-1980 1981-1990 1991-2000 2001-2010 2011-2016

Fig. 5. Dynamics of monthly rainfall at the meteorological station Kharkiv (July) 
The calculated bioclimatic potential for the studied area can be considered as a criterion for zoning the territory under similar agro-climatic conditions. It takes into account the effect of heat and moisture on crop productivity. Analysis of the total active temperatures on the territory of Kharkiv region during the growing season allows us to establish ripening of agricultural crops (Table 6). Fig. 6 shows spatial distribution of total active air temperatures characterized by an increase in the south and south-east to $3000{ }^{\circ} \mathrm{C}$ and above, accelerating phonological phases of plants.

For Kharkiv region $\mathrm{BCP}$ is characterized by generally high rates and due to increased heat resources increases from north to south. In southern, more arid areas, additional irrigation is required. More optimal conditions of humidification are found in the north of the region (Fig. 7).

Distribution of climatic conditions for the period 2001-2015 on the territory of Kharkiv region was assessed on the central months of the year (January, April, July, October). In winter (January) it changes mainly in the meridional direction - the highest values of climatic conditions stability index were recorded in the eastern part of the region, and the smallest in the southwest (Fig. 8). Such distribution of climatic indicators is determined by the peculiarities of physical and geographical conditions of the territory, as well as by atmospheric circulation fluctuations in winter. The eastern part of the region is characterized by rather low indicators of air temperature and rainfall, but due to high wind power indicators it is more favorable for economic activity. In general, the territory of the region during the winter period is characterized by a satisfactory assessment of weather conditions (4.4-5.6 points).

In spring (April), the coefficient of climatic conditions stability varies in latitudinal direction - the values increase from south-east to northwest. The highest rates are recorded in the northern and eastern parts of the region, characterized by a more stable temperature regime. Given that in spring atmospheric circulation is quite variable (alternating cold and warm air masses), there are quite significant fluctuations of air temperature and wind speeds.

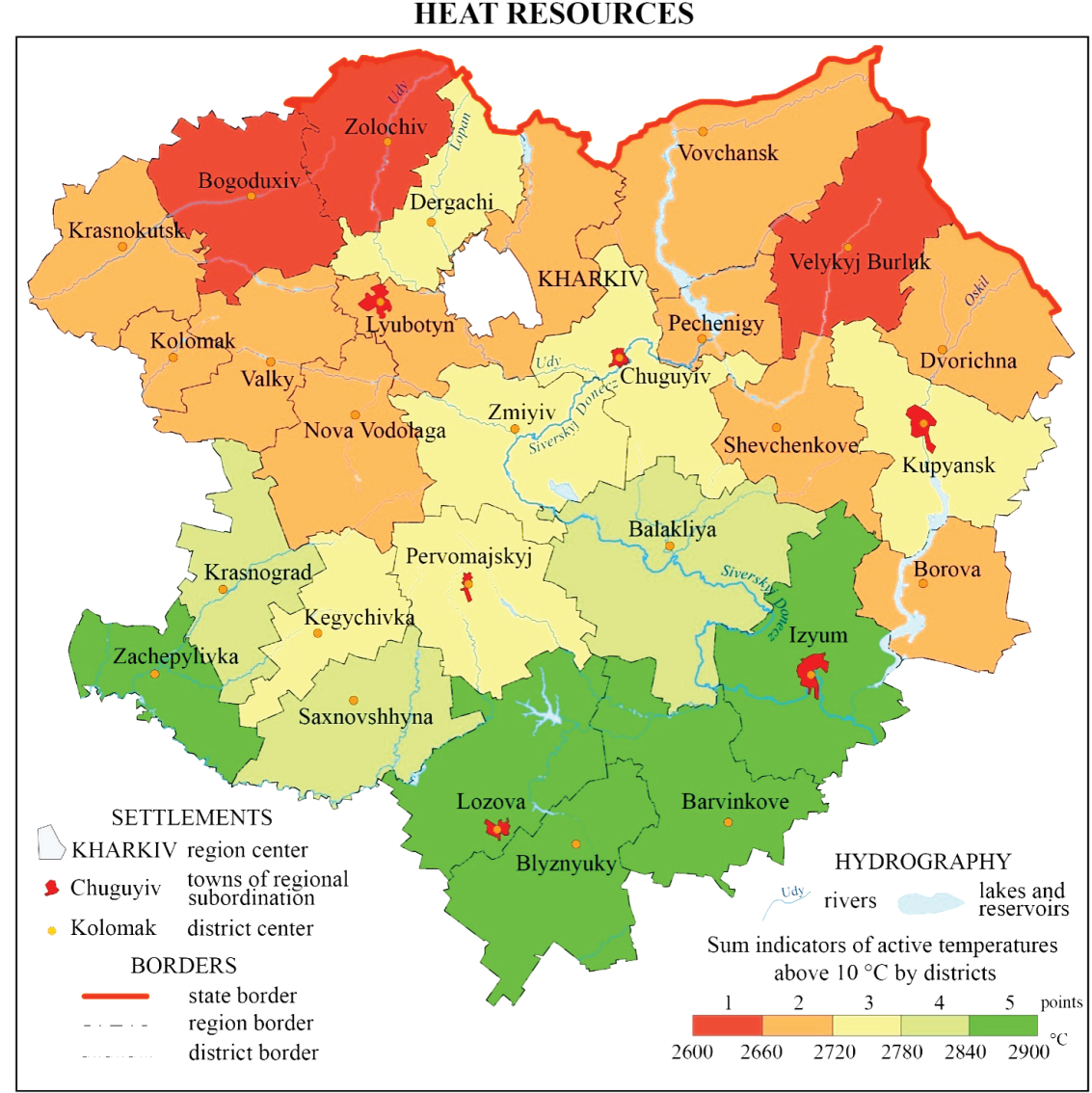

1:1500 000

Fig. 6. Heat resources on the territory of Kharkiv region

BIOCLIMATIC POTENTIAL

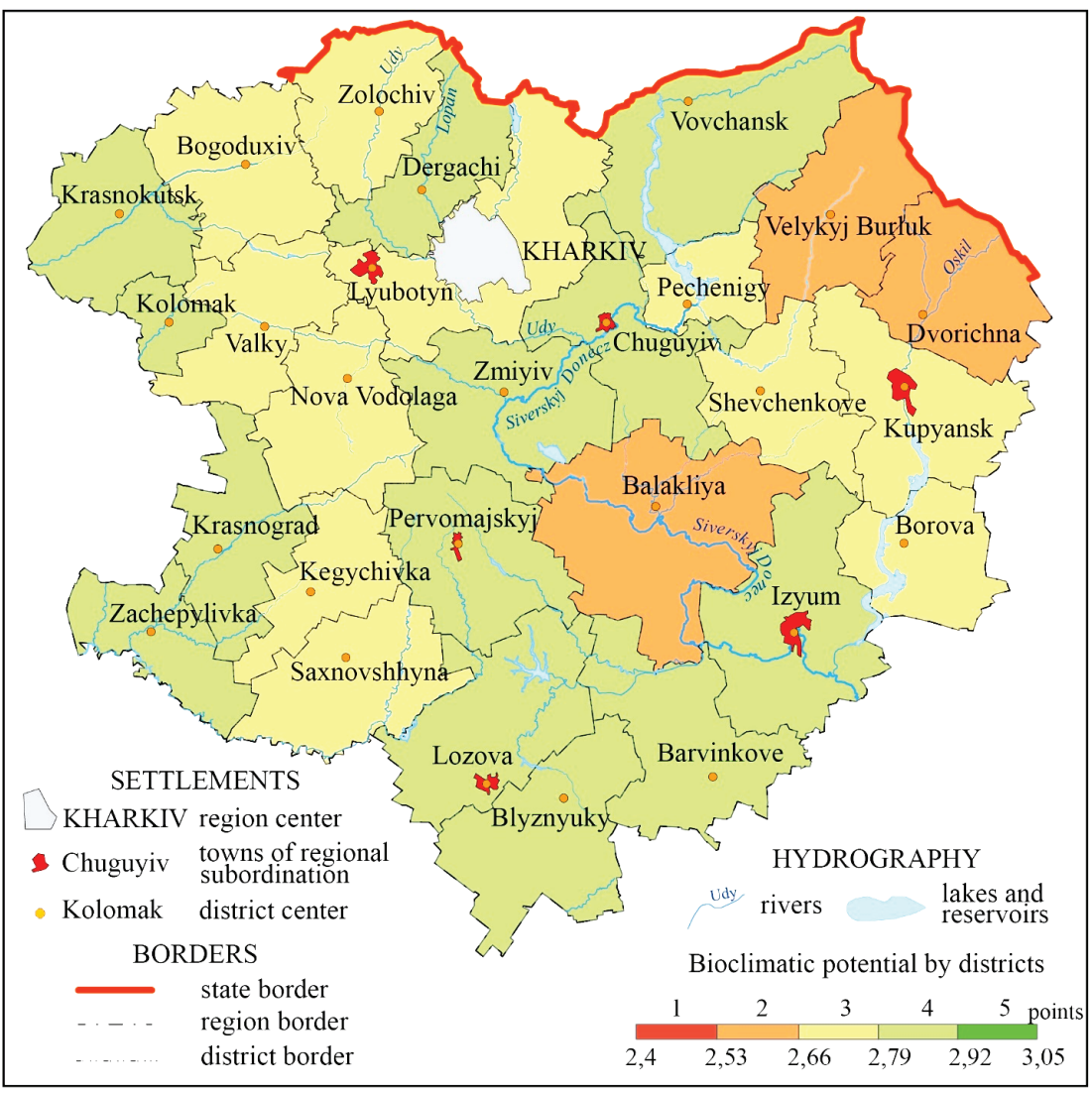

$1: 1500000$

Fig. 7. Bioclimatic potential of Kharkiv region 


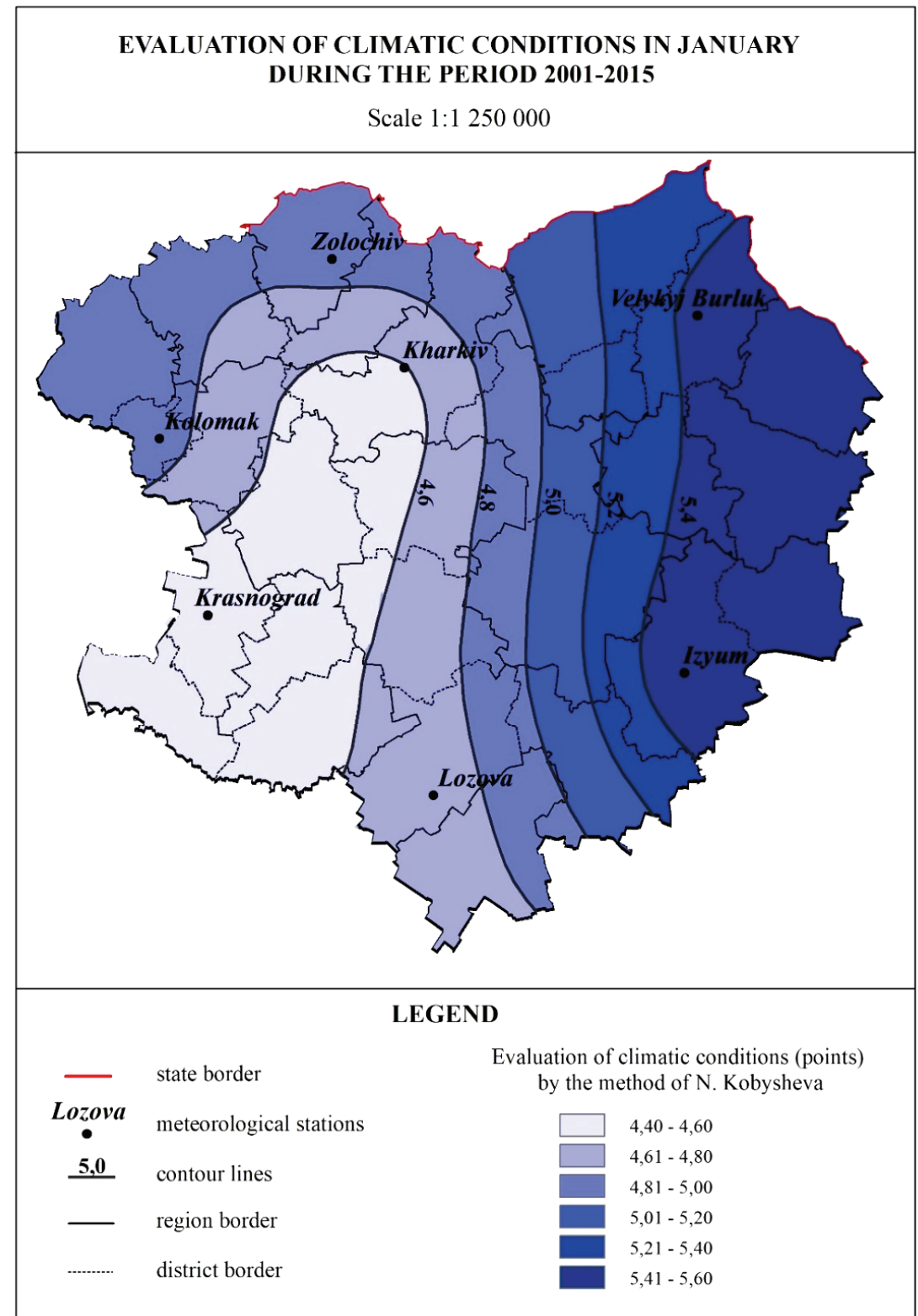

Fig. 8. Evaluation of climatic conditions in January

Since the south-western part of the region is open, the weather volatility index is the highest on the territory. In general, in spring Kharkiv region is characterized by satisfactory indicators of weather conditions (3.4-4.7 points).

Temperature and wind conditions are mainly characterized by permanency because the amplitude of oscillations is low during the warm period of the year (Fig. 9). This can be explained by dominating radiation factor in the formation of climatic conditions on the territory of Kharkiv region in summer. The lowest estimates of climatic conditions are observed in the northern and southern parts of the region due to the arrival of a large amount of precipitation in the southwestern cyclones. Temperature decreases and wind speed increases, there are rains, thunderstorms. Underlying surface also plays a significant role: as the territory in the south of the region is open and less populated (low rural buildings prevail), there are no natural and man-made barriers for the movement of atmospheric air masses. Accordingly, the amplitude of the oscillations of wind speeds is sig- nificant, which reduces stability of weather conditions in the area. It has been determined that the territory of Kharkiv region in the summer period is characterized by a satisfactory assessment of climatic conditions (3.9-5.4 points).

In autumn the coefficient of climatic conditions stability varies mainly in latitudinal direction. Northern and northeastern parts of the region are characterized by the lowest indicators due to a deviation in the direction of temperature increase although sometimes there are sharp cold fluctuations in early October (caused by the inflow of cold air from the Arctic or Siberia). Thus, the amplitudes of air temperature fluctuations are significant enough to destabilize climatic conditions in the north. The southern and southwestern parts of the studied area have a higher index of weather stability due to the established air temperature regime and nature of the underlying surface. It has been established that in October the territory of Kharkiv region has satisfactory assessment of weather conditions (4.0-5.2 points). 


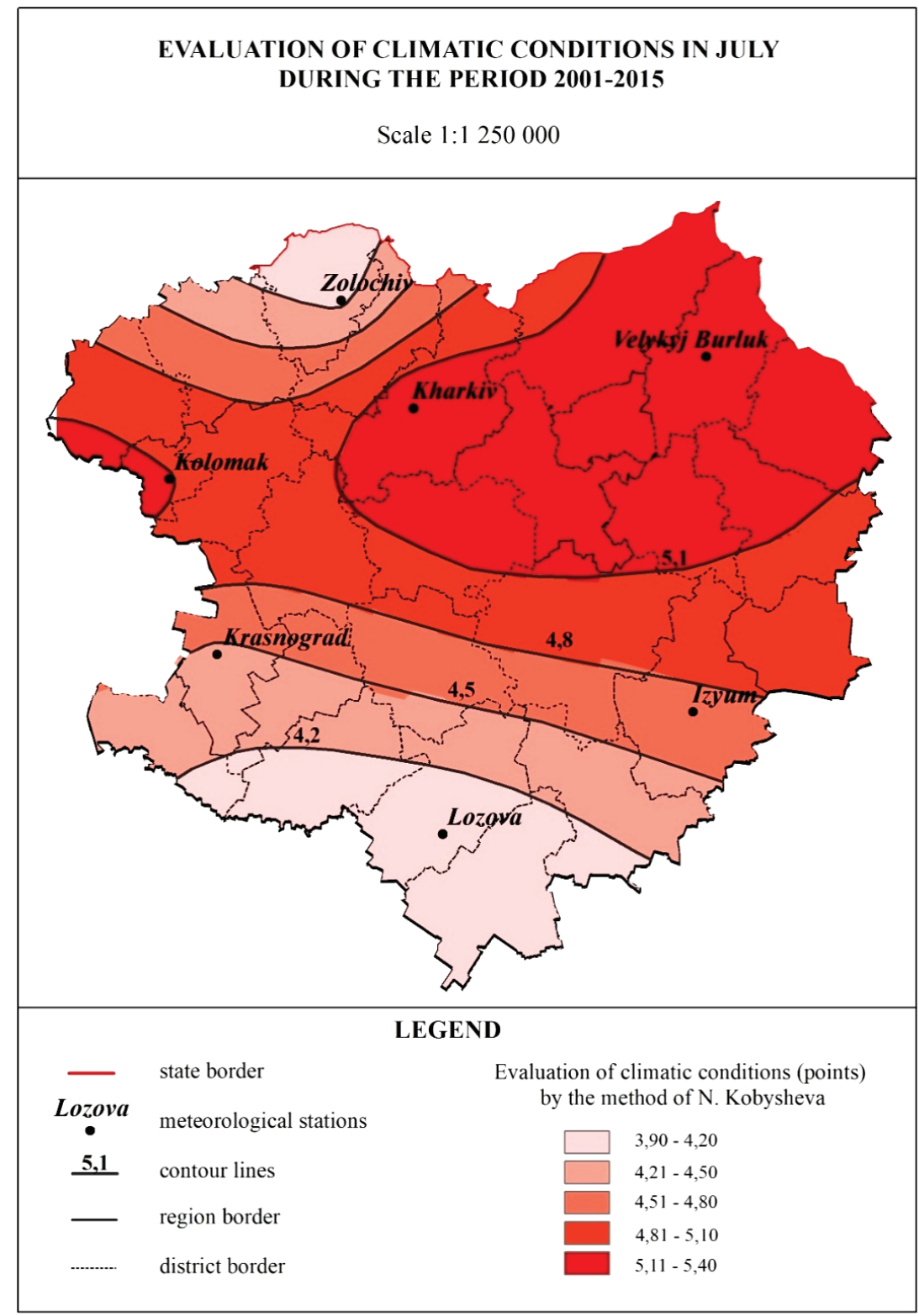

Fig. 9. Evaluation of climatic conditions in July

\section{SWOT analysis of research results}

Strengths. The study comprehensively assesses and characterizes the agricultural potential of the area, which creates food security of the country, as to heat and moisture resources. Thus, the analysis of the main characteristics of the temperature regime in Kharkiv region shows that an earlier transition of air temperature is expected through $0{ }^{\circ} \mathrm{C}$ for $7-15$ days. In autumn temperature change through $0{ }^{\circ} \mathrm{C}$ will be $13-18$ days later. There is a significant increase in the period duration with active air temperatures. The sums of active air temperatures have increased from 2400 to $3900{ }^{\circ} \mathrm{C}$, which corresponds to an increase in the heat supply of plants and ripening of late crop varieties. In general, heat supply has increased in the south of the region. Assessment of agro-climatic resources of Kharkiv region makes it possible to assert that during the summer and autumn periods the territory has rather comfortable and favorable conditions for the life of agroecocoenosis. In return, significant fluctuations of climatic indicators can be expected in the winter-spring period characterized by rather mild but unstable weather conditions because of the wind regime.

Modern fluctuations of climatic indicators will improve the conditions for cultivation of major cereals (winter, summer, early and late varieties), which can become a factor in obtaining high yields. They will increase the food security of the country and its export component. Such changes will provoke development of related industries: mineral fertilizers and agricultural machinery.

Weaknesses. The increase in the sum of active temperatures in Ukraine will change distribution of agro-climatic zones, shifting to the north. Thus, the climatic conditions of the southern part of the steppe may correspond to a moderately hot subtropical belt. Such changes will contribute to significant changes in crops. But the forecast based only on the sums of active temperatures is not correct enough, since the present agro-climatic zones in Ukraine are allocated considering the conditions required for the cultivation of modern crops adapted to a certain 
level of humidification, soil type and methods of agrotechnics. Therefore, it is necessary to consider changes in the humidity conditions in Ukraine against the background of global climate change [25].

The insufficient moisture regime contributes to the increased likelihood of droughts, dry winds, which will increase the frequency of fires and desertification of the territory. Instead, in southern regions, which today are the major suppliers of grain, due to the increase in the average annual temperature of air by $1-2{ }^{\circ} \mathrm{C}$, frequency of arid phenomena may increase, and a zone of unstable and insufficient soil moisture will spread to central and northern regions. Reduction of groundwater level is also possible as well as the spread of new diseases and pests of plants through an increase in the warm period, salinization of soils and their waterlogging through warm winters which, in general, will reduce the productivity of agricultural production.

Opportunities. This kind of changes in agroclimatic conditions will lead to introduction of new agrotechnical measures for soil and crops cultivation. It can be assumed that an increase in the length of the growing season will be effective for the agriculture of the northern and central part of Ukraine. Increase in duration of the growing season will increase crops production. It can be predicted that an increase in heat resources will prolong agricultural seasons and will make it possible to produce two crops. The country will be able to grow more winter wheat subject to change the sowing and harvest time, while the use of frost resistant varieties of crops will reduce. Consequently, in accordance with international agreements, it is necessary to implement measures to adapt the Ukrainian economy, in particular, agriculture to the climate change.

In the future, it is planned to consider the agricultural potential of Ukraine and Kharkiv region according to separate crops that have their own requirements to climatic indicators and to determine their rational placement with the identification of the most favorable conditions for cultivation.

Further comparative analysis of the normalized NDVI vegetation index distribution with indicators of agricultural crops yield (winter wheat, spring wheat, sunflower, corn) on the territory of Kharkiv region will help to establish the trend of crop yields and the meteorological component of its variability. Taking into account that the established trends in agro-climatic resources change extend to the whole of Eastern Europe territory [26, 27], the obtained results are valuable not only in the national but also in the pan-European context. The proposed measures of agriculture adaptation to modern climate change can be successfully applied in neighboring countries, in particular, Moldova, Belarus.

Threats. Among the threats to agriculture can be noted:

- unevenness of rainfall during certain periods of the year;

- sharp temperature fluctuations between seasons and during individual months;

- lack of stable snow cover;

- increase in the number of days with high temperatures;

- increasing frequency of extreme weather events, in particular, increasing number of drywaves.

Moisture regime is an important climatic factor for stable yields. According to studies, $35-80 \%$ of wheat and barley yields depend on rainfall, which can form unstable agricul- tural production. It should be noted that displacement of natural zones will trigger the mechanism of soil destruction and degradation. As Ukrainian black earths are characterized by a high content of organic matter, in conditions of climate change it can either increase or decrease.

Objective difficulties arise in determining the reliability of various indices regarding the agroecocoenoses conditions vulnerable to the variability of meteorological parameters in space and time. The multiplicity of interconnections between these components complicates the methodology for their calculations. But they can be used to monitor droughts, general condition of vegetation cover.

\section{Conclusions}

1. A statistical analysis of the main agro-climatic indicators was carried out and the peculiarities of their spatial distribution on the territory of Ukraine during the periods 1891-1935 and 1935-1960 were determined. The agroclimatic parameters characterizing the heat resources were obtained based on the data of the average monthly air temperatures and rainfall. An increase in the sums of active and effective air temperatures indicates an increase in the heat supply of the country.

2. Agro-climatic indicators at the regional level are calculated on the example of the territory of Kharkiv region for the period of 2001-2014. Recent changes in climatic conditions are characterized by:

- an increase in the average monthly air temperature and higher repeatability of high temperatures;

- decrease in the stability of the snow cover and dura-

tion of the winter period;

- decrease in the amount of precipitation in summer and autumn;

- increased dryness in the east and south of the region. In general, heat supply is increasing in the southern regions of Kharkiv region making them more bioclimatically potential.

3. The ecological conditions of agro-climatic resources of the territory of Kharkiv region have been estimated. They have showed changes in the stability coefficient of climatic conditions by seasons on average from 3 to 5 points where the most favorable for agroecocoenoses is summer and autumn.

4. Possible measures for adaptation of agriculture to modern changes of agro-climatic resources have been determined. Based on the obtained results, Kharkiv region has the following possibilities:

- sufficient amount of heat makes it possible to grow heat-loving plants, late-ripening varieties;

- it is possible to increase spring crops as well as winter crops, to introduce varieties that are not demanding moisture and are «tolerant» to sharp fluctuations and high temperatures. It is advisable for Ukraine to grow late-ripening crops due to increasing heat resources.

\section{References}

1. Transforming our world: the 2030 Agenda for Sustainable Development // UN General Assembly, 2015. URL: http://www refworld.org/docid/57b6e3e44.html (Last accessed: 11.06.2017).

2. Tarariko O. H. SWOT-analiz i analiz prohalyn (GAP-analiz) polityk, prohram, planiv i zakonodavchykh aktiv u haluzi silskoho hospodarstva ta pidhotovka rekomendatsii shchodo yikh udoskonalennia vidpovidno do polozhen Konventsii Rio. Kherson: FOP Hrin D. S., 2016. 102 p. 
3. Climate Change in Eastern Europe. Belarus, Moldova, Ukraine. ENVSEC, Zoi environment network, 2012. 59 p.

4. Iedyna kompleksna stratehiia ta plan dii rozvytku silskoho hospodarstva ta silskykh terytorii v Ukraini na 2015-2020 roky: proekt vid 26 zhovtnia 2015 roku. Ministerstvo ahrarnoi polityky ta prodovolstva Ukrainy, 2015. $94 \mathrm{p}$.

5. Stratehiia staloho rozvytku Ukrainy na period do 2030 roku: proekt vid 29.12.2016. Versiia 3.4. 2016. URL: http://bit.ly/ 2t8QY6V (Last accessed: 11.06.2017).

6. Klimatychnyy kadastr Ukrayiny / ed. by Kosovets O. O. et al. Kyiv: Derzhavna Hidrometeorolohichna sluzhba, UkrNDHMI, TS.HO, 2006. 1 elektron. opt. dysk (CD-R).

7. Boichenko S. H. Napivempirychni modeli ta stsenarii hlobalnykh i rehionalnykh zmin klimatu. Kyiv: Naukova dumka, 2008. 309 p.

8. A review of climate risk information for adaptation and development planning / Wilby R. L. et al. / International Journal of Climatology. 2009. Vol. 29, No. 9. P. 1193-1215. doi: http:// doi.org/10.1002/joc.1839

9. Vplyv zmin klimatu na silske hospodarstvo pivdnia Ukrainy / Polovyi A. M. et al. // Meteorolohiia, klimatolohiia i hidrolohiia. 2005. No. 49. P. $252-260$

10. Impacts of Climate Change and Variability on European Agriculture / Orlandini S. et al. // Annals of the New York Academy of Sciences. 2008. Vol. 1146, No. 1. P. 338-353. doi: http://doi.org/10.1196/annals.1446.013

11. Impacts and adaptation of European crop production systems to climate change / Olesen J. E. et al. // European Journal of Agronomy. 2011. Vol. 34, No. 2. P. 96-112. doi: http://doi.org/ 10.1016/j.eja.2010.11.003

12. Methodologies for simulating impacts of climate change on crop production / White J. W. et al. // Field Crops Research. 2011. Vol. 124, No. 3. P. 357-368. doi: http://doi.org/10.1016/ j.fcr.2011.07.001

13. Agroclimatic conditions in Europe under climate change / Trnka M. et al. // Global Change Biology. 2011. Vol. 17, No. 7. P. 2298 2318. doi: http://doi.org/10.1111/j.1365-2486.2011.02396.x

14. Features of climate change on Ukraine: scenarios, consequences for nature and agroecosystems / Boychenko S. et al. // Proceedings of the National Aviation University. 2016. Vol. 69, No. 4. P. 96-113. doi: http://doi.org/10.18372/2306-1472.69.11061

15. Mishhenko Z. A., Kirnasovskaya N. V. Agroklimaticheskie resursy Ukrainy i urozhay. Odessa: Ekologiya, 2011. 296 p.

16. Use of NDVI and Land Surface Temperature for Drought Assessment: Merits and Limitations / Karnieli A. et al. // Journal of Climate. 2010. Vol. 23, No. 3. P. 618-633. doi: http://doi.org/ 10.1175/2009jcli2900.1

17. Bouma E. Development of comparable agro-climatic zones for the international exchange of data on the efficacy and crop safety of plant protection products // EPPO Bulletin. 2005. Vol. 35, No. 2. P. 233-238. doi: http://doi.org/10.1111/j.13652338.2005.00830.x

18. Bozhko L. Yu. Otsinka vplyvu ekstremalnykh yavyshch na produktyvnist silskohospodarskykh kultur. Odessa, 2013. $240 \mathrm{p}$

19. Trofymova I. V. Adaptaciya do zmin klimatu: naslidky, vrazlyvist, ryzyky // Environmental Safety and Natural Resources. 2011. No. 7. P. $128-135$.
20. Osadchyj V., Babichenko V. Dynamics of adverse meteorological phenomena in Ukraine // Ukrainian Geographical Journal. 2012. No. 4. P. 8-14. URL: https://ukrgeojournal.org.ua/en/node/345

21. Shkolnyi Ye. P., Popovych P. P. Doslidzhennia statystychnoi struktury polia serednomisiachnoi kilkosti opadiv dlia raioniv Ukrainy u kholodnyi period // Meteorolohiia, klimatolohiia ta hidrolohiia. 2004. No. 48. P. 5-12.

22. Otsinka vplyvu zmin klimatu na vodni resursy Ukrainy na osnovi modeli «klimat-stik» za stsenariiem hlobalnoho poteplinnia A2 / Loboda N. S., Serbova Z. F., Bozhok Yu. V. / Hidrolohiia, hidrokhimiia i hidroekolohiia. 2015. Vol. 1. P. 8-17.

23. Otsinka mozhlyvykh zmin vodnykh resursiv mistsevoho stoku v Ukraini v XXI stolitti / Snizhko S. et al. // Vodne hospodarstvo Ukrainy. 2012. No. 6. P. 8-16.

24. Ispol'zovanie vodno-balansovoy modeli turka i chislennoy regional'noy modeli Remo dlya otsenki vodnykh resursov mestnogo stoka v Ukraine v XXI veke / Snezhko S. I. et al. // Vestnik Bryanskogo gosudarstvennogo universiteta. 2014. P. 191-201.

25. Pluntke T. et al. Hydrologic Effects of Climate Change in the Western Bug Basin // Proceedings of the Global and Regional Climate Change. Kyiv, 2010. URL: https://www.ufz.de/export/ data/14/40637 Konf beitrag Kiev 2010 Pluntke.pdf

26. Williams J. W., Jackson S. T. Novel climates, no-analog communities, and ecological surprises // Frontiers in Ecology and the Environment. 2007. Vol. 5, No. 9. P. 475-482. doi: http:// doi.org/10.1890/070037

27. VanDerWal J., Shoo L. P., Williams S. E. New approaches to understanding late Quaternary climate fluctuations and refugial dynamics in Australian wet tropical rain forests // Journal of Biogeography. 2009. Vol. 36, No. 2. P. 291-301. doi: http:// doi.org/10.1111/j.1365-2699.2008.01993.x

Reshetchenko Svitlana, Lecturer, Department of Physical Geography and Cartography, V. N. Karazin Kharkiv National University,Ukraine,e-mail: swet res@meta.ua, ORCID: https://orcid.org/ 0000-0003-0744-4272

Popozych Nataliia, Senior Lecturer, Department of Physical Geography and Cartography, V. N. Karazin Kharkiv National University, Ukraine,e-mail:n.popovych@physgeo.com,ORCID: https://orcid.org/ 0000-0003-4968-6296

Shulika Boris, Senior Lecturer, Department of Physical Geography and Cartography, V. N. Karazin Kharkiv National University, Ukraine, e-mail: b.o.shulika@karazin.ua, ORCID: http://orcid.org/ 0000-0002-2427-4124

Porvan Andrey, PhD, Assistant Professor, Department of Biomedical Engineering, Khrakiv National University of Radio Electronics, Ukraine, e-mail: porvan_a_p@mail.ua, ORCID: http://orcid.org/ 0000-0001-9727-0995

Cherkashyna Nadiia, Senior Lecturer, Department of English Language, V. N. Karazin Kharkiv National University, Ukraine e-mail: n.cherka@gmail.com,ORCID: https://orcid.org/0000-00024066-2530 